\title{
PENGEMBANGAN BAHAN AJAR TENTANG SEKOLAH RAMAH ANAK PADA MATA KULIAH MANAJEMEN BERBASIS SEKOLAH
}

\author{
Hernawaty Damanik dan Sondang P. Pakpahan* \\ Surel :herna@ecampus.ut.ac.id
}

\begin{abstract}
This study aimed to find out the tutorial perception of students, teacher and headmaster of elementary school, about the management based on school which is familiar with children and children's rights, evaluation, learning material and tutorial process on learning management based on school (MBS), arrangingthe material concept and instructional model in open university (UT). This study was conducted in elementary school located in Sei Balai sub-district, Batubara regency, the province of North Sumatera. It observed the students of PGSD, lecturer, teachers and headmaster. The steps used in conducting this resign to the teaching material UT is Dick and Carrey model. The result of this research is tutorial's perception, university students, teachers and the headmaster to the modul MBS UT: (a) Good enough but it is unuseful due to the school otonomy is not specificlyimplemented to state elementary school, (b) MBS material according to students is needed to be added with school management related to HAM and children protection, (c) Most of the teachers said that they need to know about school management which are familiar to children, $(d)$ a suitable tutorial system in an opened learning university (UT) that its instructional process management school based lesson tends to have eight times meeting tutorial, and there is no assignment given thus the students do observation about practising MBS at school, (e) Material learning MBS in opened learning university (UT) needs to be modified with the six moduls, but it is more than 15 learning activities. Then it has 18 learning activities by adding the learning material about school which are familiar to the children, children's rights and children management.
\end{abstract}

Keywords : material learning, school familiar to the children, management school based.

*Dr. Hernawati Damanik, M.Pd. Dosen UPBJJ-UT Medan

*Dra. Sondang P.Pakpahan, MA. Dosen UPBJJT-UT Medan 


\section{PENDAHULUAN}

$\begin{array}{lc}\text { ermasalahan } & \text { kekerasan di } \\ \text { sekolah } & \text { merupakan } \\ \text { permasalahan } & \text { signifikan yang }\end{array}$ harus dihadapi dan dicari solusi bersama, baik masyarakat, kepala sekolah, guru, dan orangtua. Sinergitas dimaksud sangat diperlukan untuk menjaga stabilitas keamanan, kenyamanan, dan keramahan sekolah agar siswa senang belajar di sekolah. Menjaga stabilitas keamanan dan kenyamanan dankeramahan sekolah diperlukan untuk menjadikan tindakan pencegahan serta hukuman atau prevention and punishment yang menjadi lebih efektif. Pada dasarnya kekerasan (violence) merupakan suatu fenomena kompleks yang terbagi atas beberapa ketegori berdasarkan tipe, etiologi, konteks dan kepelikan permasalahannya. Selain itu, indeks kekerasan di sekolah juga tergantung pada bagaimana kekerasan tersebut didefinisikan dan diukur. Astor dan Benbenishty (2007) mengemukakan bahwa beberapa teori dan hasil penelitian mengindikasikan angka kekerasan siswa di sekolah cenderung merefleksikan angka kriminalitas dan demografi komunitas atau lingkungan masyarakat sekitar. Oleh karena itu, sekolah yang berada di dalam konteks komunitas dengan level kriminalitas yang tinggi dan dengan status sosial ekonomi yang rendah seringkali dikorelasikan dengan kecenderungan tingginya angka kekerasan di sekolah jika dibandingkan dengan level kriminalitas yang lebih rendah dan komunitas status sosial-ekonomi yang lebih tinggi.

Kekerasan terhadap anak adalah semua bentuk perlakuan salah secara fisik dan/atau emosional, penganiayaan seksual, penelantaran, atau eksploitasi secara komersial yang mengakibatkan gangguan nyata atau potensial terhadap perkembangan, kesehatan, dan kelangsungan hidup anak atau terhadap martabatnya dalam konteks hubungan yang bertanggung jawab, kepercayaan, atau kekuasaan (UNICEF dalam Damanik, 2008). Kekerasan terhadap anak dapat terjadi di berbagai tempat, seperti di rumah tangga, lingkungan sosial, dan sekolah. Anak usia di bawah 18 tahun perlu dilindungi agar terhindar dari berbagai tindakan kekerasan, baik yang dilaksanakan oleh perorangan maupun kelompok.

Menurut Arist Merdeka Sirait (http://metrotvnews.com) dari tahun 2010 hingga 2012, jumlah kasus kekerasan yang dialami anak-anak mencapai 21 juta kasus. Sementara itu, menurut Lubis, berdasarkan hasil catatan Yayasan Pusaka Indonesia (YPI) sepanjang tahun 2012, terdapat 218 anak yang menjadi korban tindak kekerasan, perlakuan yang salah, bahkan tindakan asusila di Sumatera Utara dan kota Medan merupakan daerah tertinggi terjadinya tindak kekerasan terhadap anak mencapai 72 korban, disusul Kabupaten Deli 
Serdang 29 korban dan Serdang Bedagai (http://harianandalas.com).

Kekerasan di sekolah selama ini menduduki peringkat kedua setelah kekerasan di rumah yakni sekitar 25\% dari semua kasus-kasus kekerasan yg dilaporkan ke KPAI selama tahun 2008 dan 2009. Kekerasan terhadap anak di sekolah terjadi karena beberapa sebab. Selain minimnya pengetahuan guru tentang hak-hak anak, juga karena guru yang kurang profesional, miskin metode kreatif sehingga selalu mengambil metode hukuman kekerasan untuk mendisiplinkan siswa. Angka kekerasan terhadap anak di Indonesia dinilai sudah sampai pada tingkat yang mengkhawatirkan. Setidaknya 25 juta anak Indonesia pernah mengalami kekerasan. Demikian disampaikan Linda Amalia Sari Gumelar saat menjabat Menteri Pemberdayaan Perempuan dan Perlindungan Anak di Jakarta, Jumat (19/3/2010). Oleh karena tindakan kekerasan terhadap anak makin meningkat dan situasi kekerasan terhadap anak membutuhkan perhatian serius, maka studi tentang kekerasan terhadap anak dilakukan untuk mengakselerasikan gerakan penghapusan kekerasan terhadap anak (fisik dan non fisik) karena hal itu melanggar hak anak dan mengancam martabat kemanusiaan.

Perguruan Tinggi termasuk Universitas Terbuka dapat berpartisipasi untuk mengurangi dan menghindari kekerasan terhadap anak di sekolah melalui kegiatan perkuliaan dengan cara memasukkan konsep sekolah ramah anak (child friendly school) ke dalam Modul UT. Di Universitas Terbuka (UT) sistem belajar jarah jauh (SBJJ) secara sistemik dikembangkan berpijak pada empat subsistem, yaitu:pengelolaan (registrasi, evaluasi, dandistribusi), bahan ajar, tutorial, dan ujian(UT, 2005). Dari keempat subsistem SBJJtadi, bahan ajar merupakan salah satusubsistem pokok yang berfungsi sebagaibahan ajar yang relevan agar mahasiswamemiliki banyak pengalaman belajar.Untuk meningkatkan efisiensi danefektifitas proses pembelajaran dalamSBJJ-UT, dipandang perlu mengembangkanbahan ajar yang memiliki fungsi sangatpenting dalam teknologi pembelajaran. Jikapembelajaran dapat tercapai dengan baikmaka akan dapat menunjangterhadap kualitas pendidikan, karena salahsatu masalah pokok yang dihadapi dalambidang pendidikan saat iniberkaitan dengan masalah efisiensi dan kualitas.

Modul Manajemen Berbasis Sekolah di UT merupakan mata kuliah fokus pada manajemen sekolah yang diperuntukkan bagi mahasiswa guru Sekolah Dasar. Modul MBS ini perlu dikembangkan sebaik mungkin dengan alasan sebagai berikut. Pertama, para mahasiswa perlu dibekali pengetahuan tentang kekerasan terhadap anak (child abuse), pelayanan perlindungan anak 
dan hak anak (child right) sesuai dengan Konvensi PBB. Kedua, UNICEF sejak tahun 2004 telah mengimplementasikan program Creating Learning Communities for Children (CLCC) atau Program Mendorong Masyarakat Peduli Pendidikan dengan tiga pilar utama, yaitu Manajemen dengan MBS, pembelajaran dengan PAKEM, dan upaya mendorong partisipasi masyarakat dengan PSM. Ketiga, sekolah merupakan satu tempat bagi anak-anak untuk mempersiapkan diri mereka menghadapi kehidupan masa depan, maka sekolah yang tepat bagi mereka adalah konsep sekolah ramah anak (child friendly school).

Tujuan penelitian ini adalah: (1) Melakukan survai awal terhadap tutor, mahasiswa, guru dan kepala sekolah dasar tentang persepsi dan pemahaman mereka tentang prinsipprinsip manajemen berbasis sekolah ramah anak dan hak-hak anak, (2) Mengevaluasi kurikulum/silabus matakuliah, materi/bahan ajar, proses tutorial MBS yang selama ini, dan (3) Menyusun konsep bahan ajar dan model pembelajaran mata kuliah manajemen berbasis sekolah ramah anak.

\section{PEMBAHASAN}

1. Teori Pengembangan Bahan Ajar

Teori Pengembangan Bahan Ajaryang efektif menurut Gerlach dan Ely sebagaimana dikutip oleh Karim
(1980: 70) harus memenuhi syarat: (1) ketepatan kognitif (cognitive appropriateness); (2) tingkat berpikir (level of shopisication); (3) biaya (cost); (4) ketersediaan bahan (availability); dan (5) mutu teknis (technical quality). Dalam hal pengembangan bahan ajar, Dick dan Carey (1996:228), mengajukan halhal berikut untuk diperhatikan, yakni: (1) memperhatikan motivasi belajar yang diinginkan, (2) kesesuaian materi yang diberikan, (3) mengikuti suatu urutan yang benar, (4) berisikan informasi yag dibutuhkan, dan (5) adanya latihan praktek, (6) dapat memberikan umpan balik, (7) tersedia tes yang sesuai dengan materi yang diberikan, (8) tersedia petunjuk untuk tindak lanjut ataupun kemajuan umum pembelajaran (9) tersedia petunjuk bagi peserta didik untuk tahap-tahap aktivitas yang dilakukan, dan (10) dapat diingat dan ditransfer. Romiszowski (1986: 22) mengenai pengembangan bahan ajar menyatakan bahwa pengembangan suatu bahan ajar hendaknya mempertimbangkan empat aspek, yaitu: (1) aspek akademik; (2) aspek sosial; (3) aspek rekreasi; dan (4) aspek pengembangan pribadi. Sementara itu Jolly dan Bolitho (dalam Tomsilon. ed, 1998: 96-97), mengajukan langkah-langkah pengembangan bahan ajar sebagai berikut: (1) mengidentifikasi kebutuhan materi yang perlu dibutuhkan (2) mengeksplorasi kondisi lingkungan wilayah tempat 
bahan ajar akan digunakan; (3) menentukan masalah atau topik yang sesuai dengan kenyataan yang ada di lingkungan peserta didik untuk diajarkan; dan (4) memilih pendekatan latihan dan aktivitas serta pendekatan prosedur pembelajaran, dan (5) menulis rancangan materi bahan ajar.

Mengembangkan bahan ajar dan mengaplikasikannya dalam perkuliahan/tutorial seharusnya merupakan kegiatan "bisnis" yang terus dilakukan dan dilaksanakan untuk meningkatkan kemampuan penguasaan bidang studi dimaksud. Pembelajaran dengan menggunakan bahan ajar yang didesain khusus berdasarkan kebutuhan pasar relatif masih baru karena merupakan gabungan dari kelebihan-kelebihan dari pengajaran individu lainnya seperti tujuan instruksional khusus, belajar menurut kecepatan masingmasing, balikan atau feedback yang banyak serta dapat digunakan pada kelas yang relatif besar (Nasution, 2003).

Sehubungan dengan pengajaran melalui bahan ajar, Sibuea (2000), Sibuea dan Mulyana (2002), dalam penelitian yang berbeda menyatakan bahwa penggunaan bahan ajar yang dirancang khusus mampu meningkatkan kemampuan mahasiswa secara signifikan dan strategi penerapan bahan ajar juga lebih efektif dan efisien dari pada tanpa menggunakan bahan ajar. Secara teoritis dan praktis, pengajaran melalui bahan ajar juga dapat meningkatkan mutu pendidikan secara umum dan dapat digunakan pada kelas yang besar maupun kecil dan bahkan individual. Dibandingkan dengan pembelajaran konvensional yang cenderung disajikan dalam bentuk kelompok, bahan pelajaran cenderung dalam bentuk ceramah, berorientasi pada dosen dan mengutamakan proses mengajar. Pembelajaran melalui bahan ajar disajikan secara individual, berorientasi pada kegiatan mahasiswa dengan tekanan proses belajar dan mempunyai fleksibilitas yang tinggi yang dapat disesuaikan dengan kebutuhan mahasiswa, Nasution (2003); Daryono (2001).

Merujuk pendapat di atas, bahan ajar dapat didefinisikan sebagai paket pembelajaran yang berisi satuan pelajaran terkecil yang memuat tujuan dan rangkaian kegiatan belajar yang sistematis yang memungkinkan mahasiswa mampu mempelajarinya secara individual pada tingkatan materi tertentu. Nasution (2003) menambahkan pembelajaran melalui bahan ajar juga merupakan pembelajaran yang inovatif, relatif baru dan mengacu pada prinsip atau asumsi bahwa setiap mahasiswa mempunyai kemampuan dan kecepatan belajar yang berbeda-beda. Bahan ajar penekannya pada proses belajar dan bukan proses pembelajaran (bottom-up approach).Secara teoritis dan praktis, setiap bahan ajar memiliki format dan 
desain yang berbeda-beda hal ini sangat tergantung pada pendekatan dan ahli yang mendisainnya. Tetapi pada hakikatnya, Hall dan Jones (1976) mengatakan suatu modul minimal terdiri dari lima bagian yaitu: (1) rasional, (2) pernyataan tentang tujuan, (3) penilaian awal (pre assessment), (4) kegiatan belajar, dan (5) penilaian akhir (post assessment). Sedangkan Finch dan Crunkilton (1979) mengajukan format modul harus memiliki pendahuluan, tujuan, penilaian awal, pengalaman belajar, sumber (alat) belajar, dan penilaian akhir.

Penggunaan bahan ajar dalam pembelajaran merupakan suatu usaha untuk meningkatkan kemampuan dan kompetensi mahasiswa yang dicerminkan dalam tujuan instruksional khusus dalam bahan ajar. Pengajaran modul disamping meningkatkan kemampuan dan kompetensi, pembelajaran melalui bahan ajar juga menekankan pada keterlibatan mahasiswa secara aktif dan partisipasif, menyediakan waktu yang cukup kepada mereka dan sesuai dengan kecepatan mereka masingmasing.

Pembelajaran melalui bahan ajar tidak hanya mampu meningkatkan kemampuan siswa dalam belajar bidang studi hingga 25$30 \%$ tetapi juga mampu menciptakan proses belajar mandiri, siswa merasa lebih termotivasi, berpikir mandiri dan mereka merasa lebih mudah untuk mengikuti pelajaran dan karena pengajaran modul di samping memberikan umpan balik yang cepat juga mahasiswa menerapkan konsep belajar tuntas (mastery learning) tetapi bukan pemahaman tanggungtanggung (Zainuddin, dkk.,2002; Situmorang, 2003).Sebelum merancang bahan ajar atau modul pembelajaran, memahami dan mampu mengembangkan silabus merupakan prasyarat yang diketahui penulis modul. Istilah silabus dapat didefinisikan secara sederhana sebagai garis besar, ringkasan, ikthisar atau pokok-pokok isi atau materi pelajaran (Majid, 2006). Mulyasa (2006) mengatakan silabus adalah seperangkat rencana pengaturan dan pengembangan kurikulum yang mencakup kegiatan pembelajaran, pengelolaan kurikulum dan hasil belajar dan penilaian.

Kurikulum mempunyai hubungan dengan silabus yang sangat erat, karena silabus merupakan dokumen kurikulum yang sifatnya lebih praktis, terbatas, sederhana. Sumantri (1988) dalam Majid (2006) berpendapat bahwa dalam silabus hanya tercakup bidang studi atau mata pelajaran tertentu yang harus diajarakan selama waktu setahun/satu semester. Dia lebih lanjut mengatakan bahwa silabus merupakan kerangka inti kurikulum yang berisi tiga komponen utama yang dapat menjawab permasalahan seperti a) kompetensi yang akan ditanamkan kepada siswa/mahasiswa, b) kegiatan apa yang harus dilakukan untuk mencapai kompetensi tersebut, dan c) upaya apa yang harus dilakukan untuk mengetahui 
bahwa kompetensi yang ditanamkan sudah dicapai oleh peserta didik.

Dalam kaitan penyusunan silabus mata kuliah, silabus harus memenuhi komponen-komponen yang disyarakat secara normatif. Pada dasarnya komponen-komponen silabus terdiri dari a) kompetensi dasar, b) materi, c) hasil belajar, d) indikator hasil belajar, d) penilaian, dan e) prosedur pembelajaran (Mulyasa:2006). Sejalan dengan Mulyasa, Majid mengatakan pada umumnya suatu silabus paling sedikit harus mencakup unsur-unsur: a) Tujuan mata pelajaran yang diajarakan, b) sasaran-sasaran mata pelajaran, c) keterampilan yang diperlukan agar dapat menguasai mata pelajaran tersebut, d) urutan topik-topik yang diajarkan, e) aktivitas dan sumber belajar pendukung keberhasilan belajar, dan f) berbagai teknik evaluasi yang diajarkan.

Merujuk pada beberapa pendapat di atas, sebuah silabus harus memuat a) tujuan/kompetensi pembelajaran, b) materi/urutan topik yang diajarkan, c) hasil belajar, d) indikator, e) penilian/evaluasi dan f) prosedur pembelajaran/teknik pembelajaran. Sebagai tambahan dalam rancangan silabus, alokasi waktu sumber dan alat pembelajaran perlu ditambahkan; tetapi secara substansi, sebuah silabus paling tidak memuat kompetensi dasar, materi pokok, pengalaman belajar, dan hasil belajar.

\section{Manajemen Berbasis Sekolah Ramah Anak}

Pemerintah Indonesia telah melakukan upaya-upaya untuk meningkatkan kualitas pendidikan yang mana selama ini masih dirasa masih kurang, diantaranya dengan membuat program antara lain "aku anak sekolah" dan dana bantuan operasional. Program tersebut diharapkan mampu menjunjung kualitas maupun kuantitas pendidikan di Indonesia, akan tetapi karena pengelolaannya masih terpusat dan kaku, program tersebut tidak dapat memberikan dampak positif. Dugaannya adalah masalah manajemen yang belum sesuai. Pada akhirnya, munculah suatu pemikiran atau gagasan baru dalam pengelolaan pendidikan yang memberi kebijakan kepada masing masing sekolah untuk mengatur dan melaksanakan berbagai kebijakan dari pemerintah. Pemikiran inilah yang disebut dengan manajemen berbasis sekolah. Manajemen Berbasis Sekolah di berbagai negara dapat dikemukakan sebagai berikut.

Di Hongkong MBS disebut The School Management Initiative (SMI) atau manajemensekolah inisiatif. Problem pendidikan di Hongkong yang mendorong munculnya MBS adalah strukturdan proses manajemen yang tidak memadai, peran dan tanggungjawab masing-masing pihak kurangdijabarkan secara jelas dan inisiatif datang dari atas. Model MBS Hongkong menekankan pentingnyainisiatif dari sumber daya di sekolah sebagai pengganti inisiatif dari atas yang selama itu diterapkan.Inisiatif yang diberikan kepada sekolah harus dibarengi dengan diterapkannya transparansi 
danakuntabilitas dalam pengelolaan pendidikan. Transparansi di sini juga menuntut kejelasan tugas dantanggungjawab masing-masing pihak yang terkait dengan pelaksanaan pendidikan di sekolah.Transparansi dan akuntabilitas tidak hanya dituntut dalam penggunaan anggaran belanja sekolah,tetapi juga dalam hal penentuan hasil belajar siswa serta pengukuran hasilnya (Nurckholis, 2003:88).

MBS di negara Kanada, sebelum diterapkannya MBS, kondisi awalnya adalah semua kebijakanditentukan dari pusat. Model MBS di Kanada disebut School - Site Decision Making (SSDM) ataupengambilan keputusan diserahkan pada tingkat sekolah. MBS di Kanada sudah dimulai sejak tahun1970. Desentralisasi yang diberikan kepada sekolah adalah alokasi sumber daya bagi staf pengajardan administrasi, peralatan dan pelayanan. Menurut Sungkowo (2002:16), ciri-ciri MBS di Kanadasebagai berikut: penentuan alokasi sumber daya ditentukan oleh sekolah, alokasi anggaranpendidikan dimasukkan kedalam anggaran sekolah, adanya program efektivitas guru dan adanyaprogram pengembangan profesionalisme tenaga kerja. Setiap tahun survey pendapat dilakukan olehpara siswa, guru, kepala sekolah, staf kantor wilayah dan orang tua yang memungkinkan merekamerangking tingkat kepuasan mereka tentang pengelolaan hasil pendidikan (Caldwell dan Spinksdalam Abu Duhou, 2002: 29-30).

Sistem pendidikan di AS, mula-mula secara konstitusional pemerintah pusat (state)bertanggunjawab terhadap pelaksanaan pendidikan. MBS di AS disebut Side-Based Management(SBM) yang menekankan partisipasi dari berbagai pihak. Menurut Wirt (1991) yang dikutip olehIbtisam Abu Duhou, model MBS di Amerika Serikat walaupun ada perbedaan di Negaranegarafederal, ada dua ciri utama reformasi pendidikan di Amerika Serikat sebagai implementasi dari MBS, yakni: (a). Desentralisasi administratif : kantor pusat otoritas pendidikan menunjuk tugas-tugas tertentuyang dilaksanakan oleh kepala sekolah dan guru di lingkungan sekolah. Kantor pusatmenyerahkan kewenangan ke bawah, tetapi sekolah lokal masih bertanggungjawab keatas; (b). Manajemen berbasis setempat (lokal), suatu struktur yang memberi wewenang kepada paraorang tua, guru dan kepala sekolah di masingmasing sekolah untuk menentukan prioritas,mengalokasikan anggaran, menentukan kurikulum, serta menggaji dan memberhentikan staf (Abu Duhou, 2002: 40-41).

Model MBS di Inggris disebut Grant Mainted School (GMS) atau manajemen danaswakelola pada tingkat lokal. Ada enam perubahan 
struktural guna memfasilitasi pelaksanaan MBS diInggris, yakni: (1) kurikulum nasional untuk mata pelajaran inti yang ditentukan olehpemerintah (Whitehall); (2) ada ujian nasional bagi siswa kelas 7,11 , 14 dan 16; (3) MBS dibentukuntuk mengembangkan otoritas pendidikan lokal agar dapat memperoleh bantuan dana daripemerintah; (4) adanya pembentukan sekolah lanjutan teknik kejuruan; (5) kewenangan Inner LondonEducation dilimpahkan kepada tiga belas otoritas pemerintah; (6) skema manajemen sekolah localdibentuk dengan melibatkan beberapa pihak terkait, seperti: (a) peran serta secara terbuka padamasing-masing sekolah dalam otoritas pendidikan lokal, (b) alokasi sumber daya dirumuskan oleh masing-masing sekolah, (c) ditentukan prioritas oleh masingmasing sekolah dalam membiayaikegiatannya,

memberdayakan badan pengelola pada masing-masing sekolah dalam menentukandana untuk guru dan staf, dan (e) memberikan informasi kepada orangtua mengenai prestasi guru (Abu Duhou, 2002: 36-37).DiInggris penerapan MBS dilindungi dan dikondisikan dengan adanya komitmen politik serta undangundangpendidikan yang mengatur penetapan kurikulum, pelaksanaan ujian nasional, danpengelolaan pendidikan yang melibatkan berbagai unsur masyarakat luas.
Di Australia lebih seratus tahun sampai awal tahun 1970-an pengelolaan pendidikan diaturoleh pemerintah pusat (sistem sentralistik). Terjadi perubahan pada awal tahun 1970-an dan berlanjutsampai tahun 1980-an, khususnya dalam hal pengelolaan dana dan desentralisasi administratif.Karakteristik MBS di Australia dapat dilihat dari aspek kewenangan sekolah yang meliputi: pertama,menyusun dan mengembangkan kurikulum dan proses pembelajaran untuk meningkatkan hasilbelajar siswa. Kedua, melakukan pengelolaan sekolah dapat dipilih diantara tiga kemungkinan, yaituStandart Flexibility Option (SO), Enhanced Flexibility Option-(EO ), dan Enhanced FlexibilityOption-(EO2). Ketiga, membuat perencanaan, melaksanakan dan mempertanggungjawabkan.Keempat, adanya akuntabilitas dalam pelaksanaan MBS. Kelima, menjamin dan mengusahakansumber daya manusia dan sumber daya keuangan. Keenam, adanya fleksibilitas dalam penggunaansumber daya sekolah (Nurkholis, 2003:95).

Gagasan tentang sekolah ramah anak (child-friendly school) tumbuh dari upaya pada 1990-an untuk menghubungkan konsep pendidikan berkualitas dengan Konvensi Hak Anak (CRC). Pada awal milenium baru, konsep ini terus mendapatkan momentum di dua benua. Di Asia, perwakilan dari 
negara Asia Selatan dan Asia Tenggara berpartisipasi dalam UNICEF/Save the Children dalam Workshop Lingkungan Belajar Ramah Anak di Chiang Mai, Thailand. Di Sub-Sahara Afrika, 34 negara berpartisipasi dalam Inisiatif Pendidikan AnakPerempuan Afrika memasukkan inisiatif ramah anak dan perempuan ke dalam pemprograman mereka dan indikator yang berkaitan dengan sekolah ramah anak menjadi evaluasi program mereka. Sejak itu, pendekatan sekolah ramah anak terus mempengaruhi program pendidikan dasar di seluruh dunia. Bersamaan dengan itu, sistem pendidikan di berbagai negara lain telah memulai proses "Reformasi Sekolah Menyeluruh", yang melibatkan perubahan sekolah dan sistem pendidikan dalam rangka meningkatkan hasil belajar anak, yaitu, untuk mengembangkan pendidikan yang berpusat pada anak di sekolah-sekolah ramah anak.Sekolah ramah menawarkan definisi yang komprehensif dan kualitas yang baik, pendidikan dasar berbasis hak. Pendekatan sekolah ramah anak mengakui bahwa masyarakat sekolah bertanggung jawab untuk menjangkau anak-anak tidak terdaftar di sekolah dan untuk semua anak yang rentan dan keluarga mereka. Hal ini menegaskan bahwa komunitas sekolah perlu menerima anak perempuan dan laki-laki dengan senang hati dan membawa mereka ke tempat yang aman, nyaman, dan protektif terhadap pembelajaran dan pembangunan yang berkomitmen untuk lingkungan belajar yang adil bagi semua anak dan kesetaraan gender. Pendekatan sekolah ramah anak juga menegaskan bahwa keluarga dan masyarakat perlu dilibatkan dalam kehidupan sekolah, dan sekolah perlu dilibatkan dalam kehidupan masyarakat (Beska, Miske, dan Witt, 2007: 4).

Sehubungan dengan konsep sekolah ramah anak yang akan menjadi materi tambahan dalam modul MBS UT perlu disampaikan beberapa hal berkaitan dengan konsep sekolah ramah anak. Mandiudza (2010:283-288) dalam artikel yang berjudul Child Friendly School menyimpulkan tentang karakteristik sekolah ramah anak sebagai berikut: (a) Schools that operate in the best interest of the child, respecting the child's unique background and circumstances; (b) Educational environments that are safe, healthy and protective, environments build upon the assets that children bring from homes and communities; (c) Schools that are endowed with trained teachers, adequate resources and appropriate physical, emotional and social conditions for learning; $(d)$ Schools that protect children's rights and make their voices heard; (e) Schools that promote inclusiveness, gender sensitivity, tolerance and personal empowerment.Selanjutnya, (Beska, Miske, dan Witt, 2007: 7) 
menemukan di Macedonia empat indikator sekolah ramah anak sebagai berikut: Pertama,Inclusiveness, meliputi: (a) Akses yang sama terhadap dan pendaftaran di sekolah bagi semua anak-anak terlepas dari latar belakang atau kemampuan mereka, (b) Kesetaraan antara semua anak-anak dalam proses belajar,semua anak-anak disediakan dengan kondisi yang sama untuk berpartisipasi dalam proses belajar mengajar, terlepas dari latar belakang atau kemampuan mereka, (c) Kesetaraan antara semua anak-anak di semua tingkat prestasi,semua anakanak diberi kesempatan untuk memperoleh prestasi maksimal, terlepas dari latar belakang atau kemampuan mereka. Kedua, Effectiveness, meliputi: (a) Peningkatan prestasi siswa,anak-anak mencapai potensi mereka sepenuhnya, (b) Penggunaan metode baru yang inovatif untuk meningkatkan pembelajaran siswa, anak-anak belajar dengan pemahaman di lingkungan kelas memotivasi dan sesuai dengan potensi mereka sendiri, (c) Waktu yang cukup untuk mengajar dan belajar yang efektif, anak-anak menggunakan waktu mereka di sekolah untuk mengembangkan potensi masingmasing, (d) Peningkatan promosi dan retensi mahasiswa tingkat, tingkat siswa gagal kelas dan putus sekolah rendah sampai tidak ada, (e) Peningkatan praktek mengajar dan tanggung jawab guru, sekolah menciptakan kondisi yang mendukung inisiatif individu dan mengurus pengembangan profesional dan kemajuan guru. Ketiga, Health, Safety, and Protection, meliputi: (a) Siswa dalam kesehatan yang baik, (b) Lingkungan sekolah sangat aman dan protektif, (c) Rendah kejadian luka fisik di lingkungan sekolah (dan dalam perjalanan ke dan dari sekolah dan rumah), (d) Rendah terjadi perilaku kekerasan, gangguan, kekerasan, dan penyalahgunaan anakanak di lingkungan sekolah. Keempat, Gender Responsiveness, meliputi: (a) Perempuan dan anak laki-laki memiliki akses yang sama, pendaftaran dan penyelesaian sekolah, (b) Ada kesetaraan dalam proses pembelajaran bagi anak lakilaki dan perempuan, (c) Ada kesetaraan hasil belajar untuk anak perempuan dan anak laki-laki (semua anak mencapai kemampuan mereka sepenuhnya) .

Berdasarkan penelitian penelitian kuasi ekperimen selama tahun 2002/3 sampai tahun 2004/5 yang diprakarsai oleh Word Bank Institute (2010:13) ditemukan bahwa sekolah-sekolah yang telah menerapkan MBS telah menunjukkan peningkatan hasil belajar secara signifikan dalam mata pelajaran Matematika, IPA dan Bahasa Inggris. Di sisi lain, UNESCO (2001) menegaskan bahwa sekolah ramah anak (child friendly school) menjamin kualitas pendidikan dan pembelajaran yang positif bagi anak. Dengan 
menggunakan kedua konsep ini, maka sekolah ramah anak difokuskan pada: (1) sikap terhadap siswa, (2) metode pembelajaran yang berpusat pada siswa, dan menyenangkan, (3) pengelolaan kelas yang kondusif, (4) lingkungan yang sehat, (5) bebas kekerasan, (6) peran orangtua dan masyarakat, serta (7) langkahlangkah yang diusulkan oleh Rudolf Dreikurs (Taruna, 2007). Dreikurs menawarkan 10 langkah menuju Sekolah Ramah Anak, yaitu: (a) menjadikan guru sebagai pembimbing kelas/mata pelajaran;

mengutamakan keramahtamahan/ kelembutan suara; (c) memperbanyak ajakan dari pada perintah, (d) menghindari hal-hal yang menekan peserta didik, (e) memberi motivasi dan stimulasi, (f) menjauhkan sikap guru yang ingin "menguasai" siswa diganti dengan membangun keberanian/kepercayaan diri peserta didik; (g) menjauhkan diri dari mencari-cari kesalahan peserta didik, dan mengakui prestasi sekecil apa pun; (h) mengganti kata-kata guru, "Aku yang menentukan, kalian menurut saja apa perintahku", dengan "Saya anjurkan/minta, mari kalian ikut menentukannya juga"; melibatkan peserta didik menyusun peraturan sekolah atau mendaftar perilaku yang baik yang harus ditunjukkan, baik oleh guru maupun peserta didik; dan (j) melibatkan pihak orangtua (stakeholder pendidikan) dalam memfasilitasi halhal yang bermanfaat kepada sekolah.
Singkatnya, manajemen berbasis sekolah ramah anak (MBSRA) merupakan pengelolaan sekolah yang mengintegrasikan konsep sekolah ramah anak. Dengan menerapkan MBSRA diharapkan sekolah bebas dari segala bentuk tindakan kekerasan terhadap anak-anak, baik fisik maupun non fisik, oleh siapa pun.

\section{PENUTUP}

Modul Manajemen Berbasis Sekolah di UT merupakan mata kuliah fokus pada manajemen sekolah yang diperuntukkan bagi mahasiswa guru Sekolah Dasar. Modul MBS ini perlu dikembangkan sebaik mungkin dengan alasan sebagai berikut. Pertama, para mahasiswa perlu dibekali pengetahuan tentang kekerasan terhadap anak (child abuse), pelayanan perlindungan anak dan hak anak (child right) sesuai dengan Konvensi PBB. Kedua, UNICEF sejak tahun 2004 telah mengimplementasikan program Creating Learning Communities for Children (CLCC) atau Program Mendorong Masyarakat Peduli Pendidikan dengan tiga pilar utama, yaitu Manajemen dengan MBS, pembelajaran dengan PAKEM, dan upaya mendorong partisipasi masyarakat dengan PSM. Ketiga, sekolah merupakan satu tempat bagi anak-anak untuk mempersiapkan diri mereka menghadapi kehidupan masa depan, maka sekolah yang tepat bagi 
mereka adalah konsep sekolah ramah anak (child friendly school).

\section{DAFTAR PUSTAKA}

Abu Duhou Ibtisam, 2003. School based management (manajemen berbasis sekolah),UNESCO,

Penerjemah: Noryamin Aini, Suparto, Penyunting: Achmad Syahid, Abas Aljauhari. Jakarta: Logos, 2002).

Damanik, Sulaiman Zuhdi, 2008. Sekolah Ramah Anak. Banda Aceh: Pusat Kajian dan Perlindungan Anak.

Dick, Walter dan Lou Carey. (1996). The Systematic Design of Instruction. New York: Longman

Majid, Abdul. 2006. Perencanaan Pembelajaran. Bandung: PT Remaja Rosdakarya.

Mandiudza,Leona Child Friendly School, "Greener Journal of Educational Research",Vol. 3 (6), pp. 283-288, August 2013.

Nasution. 2003. Berbagai Pendekatan dalam Proses Belajar Mengajar.Jakarta: Penerbit Bumi Aksara.

Nurkholis, 2003. Manajemen Berbasis Sekolah, Teori, Model dan Aplikasi. Jakarta: PT.Gramedia Widiasarana Indonesia.
Romiszowski. (1986) Developing Auto Instructional Materials. Philedelphia: Nicolas Publishing.

Sirait, Arist Merdeka, "Kekerasan ke Anak Capai 21 Juta Kasus dalam 3 Tahun" dalam http:metrotvnews.com, 15 Mei 2013.

Taruna, J. Tukiman, "Sekolah Ramah Anak", Kompas, 29 Nopember 2007.

Tim Pengembangan Model Tutorial. 1999. Makalah Utama Dalam Rapat Koordinasin Nasional UT Tahun 1999.Jakarta: Universitas Terbuka.

Undang Undang Nomor 23 Tahun 2002 tentang Perlindungan Anak. 